\title{
Patterns of Education Financing and Debt: A Comparison of Two Cohorts of Canadian Post-Secondary Graduates *
}

\section{ROBERT D. HISCOTT}

University of Waterloo,

\begin{abstract}
Using data from 1988 and 1992 National Graduates Surveys (conducted by Statistics Canada), this paper explores educational financing and debt patterns for recent graduates of Canadian community college and university programs. A majority of recent post-secondary graduates borrowed to finance their education at some point during their educational programs through the Canada Student Loans Program and/or other sources. The more recent cohort of post-secondary graduates (1990 graduates interviewed in

* This secondary data analysis project was funded by two University of Waterloo / Social Sciences and Humanities Research Council internal research grants (1990 and 1995). This analysis is based on Statistics Canada micro data tapes which contain anonymized data collected in the National Graduates Surveys of 1986 and 1990 post-secondary graduates. All computations on these micro data were prepared by the author at the University of Waterloo, and the responsibility for the use and interpretation of these data is entirely that of the author.

I wish to thank Terry Stewart for his assistance with setting up the National Graduates Survey data for processing. Dawn Mole and Tina Chui provided research assistance with creating labeled SPSS system files for each of the two surveys examined here. I also wish to thank the editor and the two anonymous reviewers for providing helpful suggestions leading to the revised version of this paper.
\end{abstract}


1992) reported markedly higher debt loads and significantly greater amounts owing two years after graduation, relative to the earlier cohort (of 1986 graduates surveyed in 1988). Multiple regression models are developed and tested to predict the amount of debt (in dollars) owed by graduates approximately two years after completion of their programs. Key explanatory variables of (1) total amount borrowed, (2) university or community college program graduate, (3) number of months not employed between graduation and time of interview, (4) current job temporary or not, and (5) current employment income were all found to be highly significant for the most recent cohort of post-secondary graduates. However, there are important differences in multiple regression results between the two cohorts which are discussed in detail in the paper.

\section{Résumé}

En utilisant des données tirées de l'Enquête nationale auprès des diplômés menée par Statistique Canada en 1988 et 1992, l'auteur examine les tendances de divers étudiants récemment diplômés de collèges communautaires et d'universités canadiens par rapport au financement et à la dette liée à leurs études. À une moment ou à un autre pendant leur programme d'études, la majorité de ces étudiants ont eu recours à un prêt pour financier leur études, soit par l'intermédiaire du Programme canadien de prêts aux étudiants, soit d'autres sources. Comparativement à la cohorte d'étudiants postsecondaires de 1986 (sondée en 1988), celle de 1990 (sondée 1992) a déclaré des dettes beaucoup élevées et de plus importantes sommes à rembourser deux ans après l'obtention d'un diplôme. Des méthodes d'analyse par régression multiple ont été élaborées et évaluées en vue de prévoir le total de la dette (exprimée en dollars) devant être remboursée par les étudiants diplômés approximativement deux ans après qu'ils auraient terminé leur programme d'études. La présence de plusieurs variables statistiques clés permet d'expliquer la situation de la plus récente cohorte d'étudiants postsecondaires, à savoir: 1) le total des sommes d'argent empruntées; 2) le programme d'études suivi (dans une université ou un collège communautaire); 3) le nombre de mois pendant lequel l'étudiant était sans 
emploi entre l'obtention de son diplôme et sa première entrevue pour un poste; 4) la permanence ou non de l'emploi actuel de l'étudiant; 5) le revenue d'emploi actuel de l'étudiant. Il existe, cependant, des différences considérables entre les deux cohortes en question sur le plan des résultats obtenus des analyses par régression multiple; ces différences sont explicitées dans l'article.

\section{Introduction}

The debate regarding the appropriate mix of public and private (individual) funding of post-secondary education in Canada has gained new significance in light of the fiscal realities faced by all political jurisdictions in this country (namely, the severe deficit and debt problems experienced by federal and provincial governments). An increasingly common response to current fiscal problems faced in a federal state is to off-load responsibilities and financial obligations, first from one level of government to another, and then to the users or consumers of government-supported services. In the arena of post-secondary education, this is evident as universities and community colleges are forced to increase levels of student tuition and fees dramatically in order to compensate for significantly reduced operating grant transfers from respective governments.

In order to assess the potential impact on students of such significant structural changes in the funding of post-secondary education in this country, it is instructive to begin with a profile of education financing and debt patterns for previous post-secondary graduates gleaned from available survey data. How much do Canadian post-secondary graduates borrow for their education and how much do they owe on their student debts two years after graduation? To what extent do post-secondary graduates report difficulties repaying their acquired educational debts? Have patterns of personal educational financing and debt changed over time? These questions and others are addressed in this paper using data from the two most recent National Graduates Surveys conducted by Statistics Canada.

The 1992 National Graduates Survey examines the school-to-work transition and experiences of the 1990 cohort of post-secondary graduates 
(from Canadian university, community college, and trade/vocational training programs) while the 1988 survey focused on experiences reported by the 1986 cohort of graduates. The analysis provided in this paper focuses on post-secondary graduates of community college and university programs only. While this secondary analysis of these two retrospective National Graduates Surveys cannot provide an accurate reflection of the experiences of the most recent cohort of post-secondary graduates (ie: those graduating in 1996), it can certainly help in identifying important trends in education financing and debt over time (through comparison of experiences reported by two different graduate cohorts in 1988 and 1992).

\section{Literature Review}

Pursuing post-secondary education in Canada can be an expensive proposition, when one takes into account tuition and related fees, additional living expenses, foregone earnings from employment, combined with an extended duration - often three, four or more years of full-time study - for many post-secondary programs. It is therefore not surprising that many post-secondary students do not have sufficient financial resources in savings to cover all expenses during their post-secondary studies, and must borrow to meet these expenses. To this end, the Canada Student Loans (CSL) Program represents a major source of financial support for post-secondary education. As summarized by Schaafsma (1990, p. 8), "Clearly in terms of both numbers of students borrowing and the amount per borrower, the CSL Program plays a major role in enabling students to meet the financial cost of a post-secondary education." The appreciable costs associated with borrowing for postsecondary education from the student loans program and other sources are offset by the long-term human capital returns to post-secondary graduates in future earnings.

Equal access for all post-secondary students to student loans programs is essential to ensure access of all qualified students, regardless of family background and parental wealth, to opportunities for higher education (Behrman, Pollak \& Taubman, 1989). However, recent U.S. research 
has documented that despite the expressed goal of reducing inequality of access by income to higher education there remain persistent structural inequalities. Sazama (1992, p. 141) concludes that in the United States the federal student aid program "... has not affected the structure of the higher educational system. ... over time, the concentration of children from rich families is still greatest in the academically more prestigious schools regardless of the federal student financial aid program."

Similar structural inequalities can also be found in Canada with respect to participation rates in post-secondary education. As concluded by Stager in his study of university tuition fees $(1989$, p. 64$)$, “... the level of parents' education is perhaps the strongest single influence on a student's decision whether to continue to post-secondary education, and especially whether to take a university program." Given the close empirical linkage between education, employment outcomes and income, with more highly-educated individuals generally attaining better and more secure jobs with higher income levels, these patterns help produce a social class and income distribution system which is perpetuated from one generation to the next. Hence, the structural inequalities evident in one generation are passed on to the next.

Despite well-documented long-term benefits from post-secondary education derived by graduates (higher salaries, more secure jobs, a variety of extrinsic and intrinsic benefits), there are also significant shortterm costs of unemployment and underemployment experienced by recent graduates entering the Canadian labour force. With respect to employment outcomes for Canadian youth in general, there is recent evidence that ".. with the onset of the recession at the end of the decade, youth labour market outcomes have deteriorated considerably." (Betcherman \& Morisette, 1994, p. 12). Based on analysis of Labour Force Survey and other data, Betcherman and Morisette (1994, p. 3) identify trends of generally decreasing employment and an increasing rate of part-time employment among Canadian youth since 1989. They also observe that a sizeable and increasing proportion of part-time employment is involuntary in nature where part-time jobs are accepted because full-time employment is unavailable (hence, the increasing prevalence of underemployment). Further, they note that labour force 
participation of Canadian youth declined by a full five percentage points between 1990 and 1992 (Betcherman \& Morisette, 1994, p. 1).

Graduates of post-secondary programs are by no means immune to these general labour problems afflicting Canadian youth. The bleak analysis provided by Betcherman and Morisette (1994) is supported by survey research of graduates conducted by Krahn and Lowe (1991, p. 168) who conclude that the school-to-work transition is a process which has become "prolonged and made more difficult". Ashton and Lowe (1991:2) observe that the "... increasingly insecure nature of employment throughout the industrialized world - indicated by a rise in the relative numbers of casual or temporary jobs, part-time jobs, marginalized workers, and underemployment - disproportionately affects youth." Indeed, early career employment problems have become sufficiently severe that a relatively new phenomenon of lifelong learning is identified as a growing trend with younger workers more likely to move back and forth between school and work as their careers develop to maintain a competitive edge in an increasingly harsh labour market (Ashton, Green \& Lowe, 1993, p. 136).

Early career (post-graduation) employment outcomes are expected to have a substantial impact on the ability of post-secondary graduates to repay their educational debts in a timely fashion. If graduates are not employed for an extended period of time after completion of their studies or if they are employed on a part-time, casual or otherwise temporary basis, they are likely to experience more difficulties in paying down acquired debts. Given the recent youth employment trends in Canada identified by Betcherman and Morisette and others, it is reasonable to expect that more recent post-secondary graduates (i.e., 1990 graduates surveyed in 1992) will report both higher levels of student debt and more problems repaying that debt relative to earlier cohorts of Canadian postsecondary graduates.

\section{Research Methods}

The most recent National Graduates Survey conducted in 1992 has a total of 36,280 respondents with an overall response rate of $71.0 \%$. By comparison, the 1988 National Graduates Survey was somewhat larger 
based on 40,657 respondents with an overall response rate of $76.5 \%$. Each of these National Graduates Surveys is based on a systematic probability sample design, disproportionately stratified by key variables of province, level and field of study (Statistics Canada, 1988; 1992). The complex stratified sample design of the surveys and the large number of cases in each permits unbiased estimation of population parameters. Each of these large-scale national surveys is considered representative of the larger population of community college and university graduates across Canada in each of the respective survey years.

Given the disproportionate stratified sample design of each of these surveys (with differing sampling fractions for each region and each broad type of educational program) each actual survey respondent represents a different number of other graduates in each population stratum. Weighting factors are applied to the data from each survey to produce reliable population estimates. These weighting factors take into account differing sampling fractions, providing more accurate estimates of the total population of post-secondary graduates in each of the survey years. Following Statistics Canada guidelines, all derived population counts and totals (such as those presented in the debt profiles in Tables 1 and 2 further below) have been rounded to the nearest fifty units (i.e., the last two digits rounded to either " 00 " or " 50 "). Further, all income estimates for the respective populations have been rounded to the nearest $\$ 100$ unit. These rounding practices are necessary to avoid implying greater statistical precision in derived population estimates than is reasonable.

For subsequent multiple regression analyses (with results presented in Tables 3 and 4 further below), it is not appropriate to weight each sample to produce population estimates. It is, however, necessary to correct for biases in the original sample design (leading to over- or under-representation of particular groups or categories of post-secondary graduates) and this is accomplished by rescaling the weights for each case so that the overall average weight equals a value of one (1.0). Applying the rescaled weights yields results which are consistent with the original total sample sizes and which take into account the unequal probabilities of selection implicit in the original sample designs. This rescaled weighting procedure is recommended by Statistics Canada (1992, p. 32) for the type of multivariate analysis presented further below. 
Each of the two National Graduates Surveys posed a series of questions regarding personal post-secondary education financing and subsequent debt from (1) the Canada Student Loans Program and (2) other sources (such as family or friends, or direct loans through banks or other financial institutions). Standardized questions were employed in the two surveys to determine amounts borrowed (by the two broad source categories noted above) and amounts owed at the time of graduation and approximately two years after graduation (at the time of survey interviewing). The data analysis section below begins with a debt profile for graduates in each of the two survey years followed by results of multiple regression analyses predicting the total amount of education debt owed by graduates two years after completion of their post-secondary programs.

\section{Data Analysis}

Beginning with the more recent 1992 National Graduates Survey, Table 1 provides a debt profile for post-secondary graduates of community college and university programs with breakdowns by primary sources of financial support. The first panel focuses on debt acquired through the Canada Student Loans Program. Almost half of responding community college graduates and fully half of university graduates reported borrowing through the student loans program at some point during their postsecondary programs of study. Of those graduates who did borrow through this program, university program graduates borrowed almost $50 \%$ more than community college program graduates. This is entirely reasonable since university degree programs are generally longer in duration than diploma programs in community colleges and, accordingly, would require additional financial support. The differences in magnitude of student loans between community college and university program graduates carry forward to the debt loads owed both at the time of graduation and at the time of survey interviewing approximately two years after graduation. About one in five post-secondary graduates who borrowed through the student loans program, from both institution types, reported that they had experienced some difficulty in repaying their student loans since graduation. 
Table 1

\section{Student debt profile for 1990 graduates surveyed in 1992}

\begin{tabular}{lllll}
\hline & \multicolumn{2}{c}{$\begin{array}{c}\text { Community College } \\
\text { Graduates }\end{array}$} & $\begin{array}{c}\text { University } \\
\text { Graduates }\end{array}$ \\
\cline { 2 - 5 } $\begin{array}{l}\text { Student Debt Variables } \\
\text { by source }\end{array}$ & Statistic & (N) & Statistic & (N) \\
\hline
\end{tabular}

Canada Student Loans

\begin{tabular}{|c|c|c|c|c|}
\hline$\%$ ever borrowed & $45.5 \%$ & $(56,150)$ & $50.4 \%$ & $(126,050)$ \\
\hline$\$$ borrowed & $\$ 6,400$ & $(25,250)$ & $\$ 9,100$ & $(62,700)$ \\
\hline \$ owed at graduation (1990) & $\$ 5,600$ & $(24,900)$ & $\$ 7,800$ & $(62,300)$ \\
\hline \$ owed 2 yrs. post grad. (1992) & $\$ 3,900$ & $(23,050)$ & $\$ 6,000$ & $(59,750)$ \\
\hline$\%$ having difficulty repaying & $21.6 \%$ & $(18,950)$ & $20.7 \%$ & $(46,300)$ \\
\hline
\end{tabular}

\section{Other Funding Sources ${ }^{1}$}

$\begin{array}{lrrrr}\text { \% ever borrowed } & 16.5 \% & (56,150) & 23.8 \% & (126,050) \\ \text { \$ borrowed } & \$ 4,200 & (9,100) & \$ 7,200 & (29,350) \\ \text { \$ owed at graduation }(1990) & \$ 2,700 & (9,100) & \$ 4,600 & (29,000) \\ \begin{array}{l}\text { \$ owed 2 yrs. post grad. }(1992) \\ \$ 1,500\end{array} & (9,100) & \$ 3,100 & (29,100) \\ \text { \% having difficulty repaying } & 15.5 \% & (9,100) & 15.7 \% & (29,350)\end{array}$

\section{Total Funding Sources}

$\%$ ever borrowed

$$
53.6 \% \quad(56,150) \quad 60.5 \% \quad(126,150)
$$

$\$$ borrowed

$\$ 6,800$

$(29,700)$

$\$ 10,400$

$(75,050)$

$\$$ owed at graduation (1990) $\$ \$ 5,600$

$(29,300) \quad \$ 8,300$

$\$$ owed 2 yrs. post grad. (1992) $\$ 3,700$

$(27,500) \quad \$ 6,200$

$\%$ having difficulty repaying

$16.5 \%$

$(29,700)$

$16.5 \%$

1 "Other funding sources" includes loans from family or friends, as well as direct loans from banks or other financial institutions.

Source: Data from 1992 National Graduates Survey of 1990 post-secondary graduates from community college and university programs. 
Postsecondary students can also finance their education through other sources, such as loans from families or friends or direct loans from banks or other financial institutions (independent of the Canada Student Loans Program). The second panel of Table 1 profiles post-secondary education finance and debt acquired from all other sources. More modest proportions of graduates borrowed through these other sources, about one in six community college graduates and just under one-quarter of university program graduates. It is also apparent that smaller amounts were borrowed by post-secondary graduates from these other sources, relative to the loans received through the Canada Student Loans Program. This is evident from a comparison of borrowing and debt statistics for both community college and university program graduates. Consistent with these earlier patterns, a smaller proportion of graduates, less than one in six, reported having difficulties repaying loans from other sources.

The third panel of Table 1 profiles total debt acquired by post-secondary students from all sources (combining support from Canada Student Loans and other sources). Over half of graduates of both institution types indicated that they borrowed at least some money to finance their post-secondary education at some point during their programs. On average, university program graduates have borrowed approximately $\$ 3,600$ more for their education than graduates of community college programs. However, this gap narrows to about $\$ 2,500$ when comparing amounts owed approximately two years after graduation. Overall, looking at all graduates who borrowed for their post-secondary education approximately one in six graduates reported having some difficulty in repaying some part of their acquired education debts. Looking at the percentage of debt paydown (expressed relative to total original loans - not shown in Table 1), on average, community college program graduates who borrowed for their education paid off $51.5 \%$ of their educational debts, compared to $46.6 \%$ for university program graduates. A closer inspection of the debt paydown statistics reveals that $34.6 \%$ and $32.3 \%$ of borrowing community college and university graduates respectively had paid off all of their acquired debts within approximately two years after graduation from their programs. 
Table 2

\section{Student debt profile for 1986 graduates surveyed in 1988}

\begin{tabular}{lcccc}
\hline & \multicolumn{2}{c}{$\begin{array}{c}\text { Community College } \\
\text { Graduates }\end{array}$} & $\begin{array}{c}\text { University } \\
\text { Graduates }\end{array}$ \\
\cline { 2 - 5 } $\begin{array}{l}\text { Student Debt Variables } \\
\text { by source }\end{array}$ & Statistic & $(\mathrm{N})$ & Statistic & $(\mathrm{N})$ \\
\hline Canada Student Loans & & & & \\
\% ever borrowed & $43.1 \%$ & $(58,950)$ & $44.7 \%$ & $(90,100)$ \\
$\begin{array}{l}\text { \$ borrowed } \\
\text { \$ owed at graduation (1986) }\end{array}$ & $\$ 3,400$ & $(24,950)$ & $\$ 5,800$ & $(39,400)$ \\
\$ owed 2 yrs. post grad. (1988) & $\$ 2,300$ & $(24,900)$ & $\$ 4,900$ & $(39,200)$ \\
& & $(24,500)$ & $\$ 2,900$ & $(38,600)$
\end{tabular}

Other Funding Sources ${ }^{1}$

$\%$ ever borrowed

$\$$ borrowed

$13.3 \% \quad(58,950) \quad 16.5 \%$

$(90,100)$

S owed at graduation (1986) $\$ 1,700$

$(7,550)$

$\$ 4,100$

$\$$ owed 2 yrs. post grad. (1988)

$\$ 800$

$(7,550)$

$\$ 2,000$

$(7,450) \quad \$ 1,000$

\section{Total Funding Sources}

$\begin{array}{lrrrr}\text { \% ever borrowed } & 50.0 \% & (58,900) & 52.5 \% & (90,100) \\ \text { \$ borrowed } & \$ 4,600 & (29,450) & \$ 6,100 & (47,300) \\ \text { \$ owed at graduation }(1986) & \$ 3,800 & (29,450) & \$ 4,700 & (47,300) \\ \text { \$ owed 2 yrs. post grad. (1988) } & \$ 2,100 & (29,450) & \$ 2,600 & (47,300) \\ \text { \% having difficulty repaying } & 12.8 \% & (29,450) & 14.5 \% & (47,300)\end{array}$

1 "Other funding sources" includes loans from family or friends, as well as direct loans from banks or other financial institutions.

2 This information was collected for all funding, and not by specific funding source (Canada Student Loans or other funding sources).

Source: Data from 1988 National Graduates Survey of 1986 post-secondary graduates from community college and university programs. 
Table 2 provides a comparable debt profile for post-secondary graduates of community colleges and universities responding to the 1988 National Graduates Survey four years prior to the latest available survey data. Approximately half of both community college and university graduates had borrowed from some source at some point during their post-secondary programs as indicated in the third panel of Table 2. Looking carefully at the debt estimates found in this table, it is clear that the levels of borrowing and subsequent debt are more modest (compared to that reported by 1992 graduates as seen in Table 1 above) and differences in debt levels between community college and university program graduates tend to be small. All differences were found to be in the expected direction with university graduates acquiring greater debt loads for their post-secondary education relative to community college program graduates.

The differences in educational finance and debt patterns found between post-secondary graduates in 1988 and 1992 are substantial. Beginning with the percentage of graduates who borrow money for their post-secondary education from any source, there were increases of 3.6 and 8.0 percentage points for community college and university program graduates, respectively, between 1988 and 1992. Again focusing on debt from all sources (the third panel of Tables 1 and 2), for community college graduates the amounts borrowed and owed at graduation increased by close to $50 \%$ between 1988 and 1992 while the amount owed two years after graduation increased by $76 \%$ over the same period. Among university graduates, increases on all three indicators between 1988 and 1992 were found to be in the $70 \%$ range. These represent dramatic increases in debt load over a four-year time frame which far outpace levels of inflation in the general Canadian economy over the same period.

To improve understanding of the debt patterns among Canadian post-secondary graduates multiple regression models were developed to predict the amount of debt owed by post-secondary graduates approximately two years after graduation. Table 3 below provides descriptions and statistics for all variables included in tested multiple regression models. The dependent variable (student debt two years post-graduation) is measured in real dollars (measured at the time of each respective survey) 
Table 3

Dependent and independent variable descriptions and statistics

\begin{tabular}{|c|c|c|c|c|c|}
\hline \multirow{2}{*}{$\begin{array}{l}\text { Dependent Variable } \\
\text { Independent Variables }\end{array}$} & \multirow[t]{2}{*}{ Coding Details } & \multicolumn{2}{|c|}{1988 Survey } & \multicolumn{2}{|c|}{1992 Survey } \\
\hline & & Mean & S.D. & Mean & S.D. \\
\hline Student debt 2 yrs. post grad. & $\$ 0.00$ to $\$ 105,000.00^{2}$ & $2,443.403$ & $2,914.186$ & $5,523.525$ & $7,704.945$ \\
\hline Total amount borrowed & $\$ 100.00$ to $125,000.00^{2}$ & $5,510.094$ & $4,174.926$ & $9,381.067$ & $8,524.079$ \\
\hline University program graduate & $\begin{array}{l}0: \text { Community College } \\
1: \text { University }\end{array}$ & 0.616 & 0.486 & 0.717 & 0.450 \\
\hline \# Months not employed & 0 to 36 months & 3.409 & 6.838 & 2.982 & 5.645 \\
\hline Current job temporary ${ }^{1}$ & $\begin{array}{l}0: \text { all other statuses } \\
1: \text { temporary current job }\end{array}$ & 0.163 & 0.369 & 0.215 & 0.411 \\
\hline Current employment income & $\$ 1,000.00$ to $\$ 100,000.00^{2}$ & $25,694.565$ & $10,247.742$ & $29,222.773$ & $13,039.485$ \\
\hline \multicolumn{6}{|c|}{$\begin{array}{l}1 \text { "Current" refers to reference week (May 1-7, 1988, or last week prior to interviewing in June-July 1992) approxi- } \\
\text { mately } 2 \text { years after graduation. }\end{array}$} \\
\hline \multicolumn{6}{|c|}{$\begin{array}{l}2 \text { For the } 1988 \text { survey, these variables were measured using a set of ordinal categories which were then recorded as } \\
\text { interval-proximate variables (taking the midpoint value of each ordinal category). }\end{array}$} \\
\hline $\begin{array}{l}\text { Source: Data from } 1988 \\
\text { community college }\end{array}$ & $\begin{array}{l}1992 \text { National Gradua } \\
\text { university programs. }\end{array}$ & s Surveys & 986 and 1 & stsecond & raduates from \\
\hline
\end{tabular}


and represents total debt from all sources (student loan program, family or friends, direct bank loans, etc.). Note that the average amount owed by 1990 graduates in 1992 is over twice the average amount owed by 1986 graduates in 1988 .

Turning to the set of independent variables, the total amount borrowed for post-secondary education (again, from all sources) is expected to be strongly positively related to the amount owed two years post-graduation. It is reasonable to expect that those graduates who borrowed large sums of money during their post-secondary programs will need an extended time to pay off their acquired debts and that this will be reflected in appreciable amounts still owed two years after graduation. A dichotomous independent variable reflecting the type of postsecondary program completed (community college or university) is also included in the multiple regression model to capture differences between these two groups (seen especially in Table 1 for 1990 graduates but also in Table 2 for 1986 graduates). This dummy variable was coded in such a way that positive coefficients are expected (since university graduates have higher debt loads and are expected to owe more two years after graduation than community college graduates). A majority of graduates represented in each survey were from university programs, $61.6 \%$ in 1988 and $71.7 \%$ in 1992 .

Beyond conditions and status at the time of graduation from postsecondary programs, the amount owed two years post-graduation will also depend upon employment circumstances over the duration of the two year period after graduation. The number of months each graduate was not employed (either unemployed and searching for a job or out of the labour force for any reason) between the time of graduation and survey interviewing is also included in the multiple regression model. For this analysis, months of unemployed status includes voluntary and involuntary unemployment, whether the respondent was out of the labour force (due to health problems, family responsibilities, further schooling or other reasons) or was temporarily unemployed and searching for a job. All forms of non-employment are grouped together here since the primary factor is not being gainfully employed and not earning an income which could be put towards acquired student debts. This variable 
is expected to be positively related to the amount owed two years post graduation since graduates ordinarily will not be in a position to pay down acquired educational debts during periods in which they are not gainfully employed and earning an income. On average, post-secondary graduates were not employed for a relatively modest three months although there is a wide variation between graduates on this indicator (as revealed by the magnitude of the standard deviation statistics).

The amount of debt owed two years post-graduation is also expected to be a function of current employment status (reported at the time of survey interviewing). All post-secondary graduates were asked if currently held jobs were permanent or temporary. A dichotomous independent variable was constructed to indicate if current jobs were defined as temporary. It is expected that those graduates currently employed in temporary positions would owe larger student debts relative to others since temporary jobs would not provide stable income over an extended time frame which would allow for more rapid paydown of accumulated student debts. As revealed by statistics in Table 3, modest proportions of graduates were employed in temporary jobs $(16.3 \%$ and $21.5 \%$ of graduates in 1988 and 1992, respectively).

Finally, the dependent debt variable is expected to be negatively related to current employment income reported by post-secondary graduates. Those graduates with higher level incomes will have greater disposable income and accordingly be able to pay down their acquired student loans more quickly. Hence, higher income graduates are expected to owe less two years after graduation, relative to those with lower incomes from employment. As seen in Table 3, average employment incomes of post-secondary graduates increased by approximately $\$ 3,500$ between 1988 and 1992 (representing a 13.7\% increase over the four-year period). For respondents to the 1988 survey, the average educational debt owed two years after graduation represented about onefifth $(21.4 \%)$ of the average employment income of graduates. However, for 1992 post-secondary graduates the average debt-to-income ratio increased to almost one-third (32.1\%). This represents a substantial increase in the average debt-to-income ratio of ten percentage points over the four-year period. 
Table 4 below presents results from a multiple regression analysis, with models predicting the total amount of acquired student debt (in dollars) that post-secondary graduates owe approximately two years after graduation. Separate multiple regression models are run for each of the two surveys using the same set of independent variables described above to help identify important changes over time. ${ }^{1}$ A cursory inspection of the variable coefficients across the two survey data sets reveals dramatic changes in the predictors of debt load over the four-year period (1992 versus 1988). ${ }^{2}$

Beginning with the multiple regression results for the 1992 National Graduates Survey data, there are highly significant results $(\mathrm{P}<.0001)$ for all five explanatory variables. The most important predictor (as signified by a beta weight of .674) is the total amount of money borrowed or the original debt load. The final model specifies that after taking into account the remaining independent variables, for each dollar originally borrowed, approximately 61 cents is still owed two years after graduation; this represents well over half of original loans still being owed by graduates some two years after graduation. University program graduates are predicted to owe over $\$ 500$ more two years post graduation than community college graduates. This is a reasonable finding given that university programs tend to be longer in duration than community college programs which would lead to university graduates having to borrow considerably greater amounts of money for their education (as confirmed in Tables 1 and 2 above).

Each month graduates were not employed between the time of graduation and survey interviewing adds over $\$ 100$ to current loans outstanding. This is a large increment but must be understood in the context of the substantial magnitude of student debts reported by surveyed post-secondary graduates in 1992. Survey respondents whose current jobs were temporary owed over $\$ 600$ more on their student debts relative to all others. Finally, current reported income is negatively related to amount of money owed; for each dollar of employment income, there is a reduction in student debt of approximately seven cents. This negative relationship was expected since those graduates with higher income levels would be in a better financial position to pay off their educational loans earlier. 
Table 4

Multiple regression results predicting student debt (in dollars) two years after graduation

\begin{tabular}{|c|c|c|c|c|}
\hline \multirow[b]{2}{*}{ Independent Variables } & \multicolumn{2}{|c|}{$\begin{array}{c}1988 \text { Survey } \\
(N=9,973)\end{array}$} & \multicolumn{2}{|c|}{$\begin{array}{l}1992 \text { Survey } \\
(N=11,640)\end{array}$} \\
\hline & B & $\left(\mathrm{SE}_{\mathrm{B}}\right)$ & B & $\left(\mathrm{SE}_{\mathrm{B}}\right)$ \\
\hline Total amount borrowed & 0.493 & $(0.005)^{*}$ & 0.609 & $(0.006)^{*}$ \\
\hline University program graduate & -26.630 & $(45.439)$ & 538.911 & $(118.928)^{*}$ \\
\hline \# months not employed & 17.325 & $(3.083)^{*}$ & 106.949 & $(9.276)^{*}$ \\
\hline Current job temporary & 37.074 & $(57.509)$ & 659.996 & $(130.307)^{*}$ \\
\hline Current employment income & -0.031 & $(0.002)^{*}$ & -0.069 & $(0.004)^{*}$ \\
\hline Constant & 477.022 & $(64.978)^{*}$ & 986.919 & $(156.867)^{*}$ \\
\hline R Squared & \multicolumn{2}{|c|}{.506} & \multicolumn{2}{|c|}{.487} \\
\hline
\end{tabular}

* $\mathrm{P}<.0001$ (Note that unmarked variables are not significant at conventional alpha criteria levels).

Source: Data from 1988 and 1992 National Graduates Surveys of 1986 and 1990 postsecondary graduates from community college and university programs. 
By comparison, there are markedly different patterns found in the final multiple regression model for 1988 National Graduates Survey respondents. The two dichotomous independent variables (which denote university program graduates and respondents currently employed in temporary positions) are not statistically significant for this earlier postsecondary graduate cohort. The remaining independent variables are highly significant $(P<.0001)$ although the magnitude of each of the slope coefficient (B) statistics is markedly smaller than found with the 1992 survey data. For each dollar borrowed, 1986 graduates owed less than 50 cents two years after graduation. Each month respondents were not employed between graduation and the time of the survey interview added a modest $\$ 17$ to student loans remaining to be paid. Finally, for each dollar of income reported by graduates in 1988 reduced student debt by approximately three cents.

The substantial differences in the two regression models for 1988 and 1992 National Graduates Survey respondents begin with the intercept (constant) values for the equations. The intercept for the 1992 model is two times the value for the 1988 data. This also reflects the fact that the average amount owed on educational loans two years after graduation is markedly higher for the survey of more recent graduates. As indicated by the model results in Table 4, university program graduates owed much more than graduates of community college programs in 1992 while there was a negligible (non-significant) difference between graduates of the two types of institutions in 1988 (after taking the other independent variables into account). Similarly, those employed in temporary jobs in 1992 owed much more on their educational loans relative to other survey respondents in 1992 while a trivial difference was found for graduates in 1988 .

The difference between surveys in the magnitude of the slope coefficients for the amount borrowed variable reveals that the earlier cohort of post-secondary graduates were more successful in paying down their student debts within the first two years after graduation. The numeric difference, in the order of ten cents for each dollar borrowed, is further evidence that more recent post-secondary graduates require longer periods of time to pay off their student debts. This is also corroborated by 
the difference in coefficients for the independent variable reflecting number of months not employed. The increase in outstanding debt for each month not employed is fairly modest for graduates in 1988 while the effect is approximately six times greater for graduates in 1992. Given the larger educational debts for more recent graduates, any period of non-employment can be expected to have a greater effect on the magnitude of remaining educational debt two years after graduation. Finally, the negative effect of current income on amount owed is twice as great for graduates in 1992 compared to the earlier cohort in 1988. This may be related to the fact that employment incomes of graduates in 1992 are markedly higher than those found in 1988, providing more disposable income to apply to student debts.

\section{Discussion and Conclusion}

Although only four years separate the two cohorts of post-secondary graduates analyzed in this paper, the regression model statistical results are dramatically different as seen in Table 4 above. Unfortunately, these are the only two time points which can be examined using available National Graduates Surveys data sets. ${ }^{3}$ Hence, it is difficult to infer any long-term trends in educational borrowing and debt solely on the basis of these data.

In order to understand the significant differences in empirical findings between 1988 and 1992 National Graduates Surveys, it is essential to place the data analysis results in the context of the dramatically different economic climates facing the two different cohorts of post-secondary graduates. To begin, the 1986 graduates were surveyed in the middle of 1988 during a period of marked economic recovery. As evidence of this, the annual change in Gross Domestic Product (GDP) in Canada in 1988 was a very healthy $5.0 \%$ (Statistics Canada, 1995a, p. 35). By comparison, the 1990 cohort of graduates surveyed in middle of 1992 were faced with a climate of severe economic recession. For 1992 the annual change in GDP was only $0.6 \%$ (Statistics Canada, 1995b, p. 35) signifying negligible change towards the end of the recessionary period. 
The differences between a period of economic recovery and recession are also evident in key labour force indicators such as participation and unemployment rates. The overall labour force participation rate for Canada declined from $66.7 \%$ in 1988 (time of the first survey examined here) to $65.5 \%$ in 1992 (time of the second survey), a modest drop of 1.2 percentage points (Statistics Canada, 1995b, p. 34). However, the decrease in participation rates was far more significant for Canadian youth. The participation rate for youth aged 20 to 24 years was $81.0 \%$ in 1988 declining to $77.6 \%$ in 1992 , a drop of 3.4 percentage points (Statistics Canada, 1994, p. 261) in only four years. This youth age bracket ( 20 to 24 years) is especially relevant for consideration since it would encompass significant proportions of Canadian community college and university graduates.

Over the same time frame the overall unemployment rate for all Canadian workers increased from $7.8 \%$ of labour force participants in 1988 to $11.3 \%$ in 1992 , a rise of 3.5 percentage points. Once again, however, the effects of economic climate changes over the relatively short four-year time frame were more dramatic for Canadian youth. The unemployment rate for youth aged 20 to 24 rose from $11.1 \%$ in 1988 to $16.5 \%$ in 1992, an increase of 5.4 percentage points over four years (Statistics Canada, 1994, p. 219). These labour force indicators clearly demonstrate how the dramatic shift in economic climate between 1988 and 1992 negatively affected the employment opportunity structure for the latter cohort of post-secondary graduates relative to the earlier cohort.

It must also be acknowledged that the latter cohort of post-secondary graduates faced substantially higher educational costs during their programs relative to the previous cohort of graduates. A key indicator of educational costs can be seen in average university undergraduate tuition fee levels in 1985-86 (the last year of study for the cohort of graduates surveyed in 1988) and 1989-90 (the last year of study for those post-secondary graduates surveyed in 1992). Based on data presented by Martinson (1994, p. 36, see Graph 1), average undergraduate tuition fees at Canadian universities increased from about $\$ 800$ a year in 1985-86 to approximately $\$ 1,300$ a year by $1989-90$. This represents an average increase in tuition levels of about $\$ 500$ or fully $60 \%$ over the relatively 
short four-year time frame. Dramatic increases in basic educational costs as tuition fees would certainly lead to higher levels of educational borrowing, evident when comparing 1986 and 1990 post-secondary graduates (see Tables 1 and 2 above). Further, in an analysis of tuition and student aid data Drolet (1994, p. 54) found that from 1973-74 to 1991-92 tuition fees per full-time equivalent (FTE) student were always higher than student aid per FTE and, more importantly, that the gap between tuition fees and student aid has grown wider over time. These trends point to the increasing importance of formal funding programs such as the Canada Student Loans Program as mechanisms for helping students reach their educational goals. It is likely that the demand for assistance through the Canada Student Loans Program will increase considerably as the costs of post-secondary education rise over time.

The increases in basic educational costs would have a greater effect upon those in university programs (generally engaged in longer duration programs with higher costs for tuition and fees, books and equipment, etc.) relative to students in community college programs. This effect is clearly evident in total borrowing data found in Tables 1 and 2 above. For the cohort of 1986 graduates, university program graduates borrowed on average $\$ 1,500$ more than graduates of community college programs while for the cohort of 1990 graduates this average difference in borrowing had increased to $\$ 3,600$. These borrowing gaps are subsequently reflected in average dollar amounts owed two years after graduation. Hence, it is reasonable that the multiple regression modeling exercise reveals that in 1992 university graduates owed significantly more than community college graduates two years after graduation while the difference between graduates of the two program types in 1988 was trivial and non-significant. The widening gap in borrowing and debt patterns between university and community college graduates can be expected to continue given recent evidence of dramatically increasing tuition fee levels faced by post-secondary students across Canada.

Finally, the National Graduates Surveys results profiled in this paper point to the fact that post-graduation early career employment outcomes are becoming increasingly important predictors of the ability of post-secondary graduates to service their increasingly heavy acquired debt loads. 
Those graduates who experience an extended period of unemployment or underemployment following graduation or who end up in temporary jobs even two years after graduation are especially vulnerable and less able to pay down their educational debts in a timely fashion. These early career experience variables take on even greater importance as aggregate and individual levels of educational borrowing increase substantially over time.

This secondary data analysis has focused on experiences of Canadian post-secondary graduates at two distinct time points characterized by very different economic climates or circumstances. The first cohort examined (1986 post-secondary graduates surveyed in 1988) had the good fortune to have entered the Canadian labour force during a time of rapid economic recovery while the second cohort (1990 graduates surveyed in 1992) faced more limited or restricted opportunities during a severe economic recession. The changing economic climate between the two surveys can certainly account for a great deal of the observed differences in educational borrowing and debt patterns over time. However, given the dramatically different economic climate or context confronted by these two different cohorts of post-secondary graduates it is difficult to predict with precision the educational borrowing and debt patterns for future cohorts. It is hoped that comparable surveys will be conducted in future to provide further evidence for longitudinal analysis of trends and patterns on a topic of critical importance to future cohorts of Canadian post-secondary students and graduates.

\section{Notes}

1 To test the stability of the basic model, the 1988 survey regression was re-run excluding the non-significant independent variables of "University Program Graduate" and "Current Job Temporary". The results of this second regression model run revealed negligible changes in the magnitude of equation coefficients for remaining variables (relative to the first model). The revised equation is expressed as: $\mathrm{Y}=0.493$ (Total Amount Borrowed) +17.479 (Months Unemployed) - 0.032 (Employment Income) + 483.364. 
2 As a further indication of the stability of the regression models for both cohorts of post-secondary graduates it should be noted that there was no evidence of high intercorrelation between independent variables (or statistical multicollinearity). The largest bivariate $r^{2}$ value found between independent variables in the two survey data sets was .10 in magnitude indicating only $10 \%$ shared variance between the pair of variables.

3 Earlier National Graduates Surveys conducted in 1978 (surveying 1976 post-secondary graduates) and 1984 (surveying 1982 graduates) did not contain sufficient information on educational borrowing and debt repayment to allow a comparable detailed analysis to the one performed here. These two earlier surveys contained very few specific questions on educational borrowing and acquired debt relative to the latter two National Graduates Surveys analyzed in this paper.

\section{References}

Ashton, D., \& Lowe, G. (1991). School-to-work transitions in Britain and Canada: A comparative perspective. In D. Ashton \& G. Lowe (Eds.), Making their way: Education, training and the labour market in Canada and Britain, (Chapter 1). Great Britain: Open University Press.

Ashton, D., Green, F., \& Lowe, G. (1993). The linkages between education and employment in Canada and the United Kingdom: A comparative analysis. Comparative Education, 29(2), 125-143.

Behrman, J., Pollak, R., \& Taubman, P. (1989). Family resources, family size, and access to financing for college education. Journal of Political Economy, 97(2), 398-419.

Betcherman, G., \& Morisette, R. (1994). Recent youth labour market experiences in Canada. Analytical Studies Branch Research Paper \#63. Ottawa, ON: Statistics Canada.

Drolet, A. (1994). The increase in tuition fees: How to make ends meet? Education Quarterly Review, I(Spring), (Statistics Canada Catalogue 81-003), 51-55.

Krahn, H. (1991). The changing Canadian labour market. In D. Ashton \& G. Lowe (Eds.), Making their way: Education, training and the labour market in Canada and Britain, (Chapter 2). Great Britain: Open University Press. 
Krahn, H., \& Lowe, G. (1991). Transitions to work: Findings from a longitudinal study of high-school and university graduates in three Canadian cities. The changing Canadian labour market. In D. Ashton \& G. Lowe (Eds.), Making their way: Education, training and the labour market in Canada and Britain, (Chapter 7). Great Britain: Open University Press.

Martinson, M. (1994). University enrolment and tuition fees. Education Quarterly Review 1(4, Spring), (Statistics Canada Catalogue 81-003) 36-43.

Sazama, G. (1992). Has federal student aid contributed to equality in higher education? A method of measurement. American Journal of Economics and Sociology, 51(2), 129-146.

Schaafsma, J. (1990). The Canada student loans program: Time for revision. The Canadian Journal of Higher Education, 20(1), 7-20.

Stager, D. (1989). Focus on fees: Alternative policies for university tuition fees. Toronto, Ontario: Council of Ontario Universities.

Statistics Canada. (1988). Survey of 1986 graduates : Information manual. Ottawa: Household Surveys Division, Statistics Canada.

Statistics Canada. (1992). User's guide for the public microdata file survey of 1990 graduates. Ottawa: Special Surveys Group, Statistics Canada.

Statistics Canada. (1994). Historical labour force statistics. (Catalogue 71-201 Annual).

Statistics Canada. (1995a). Social indicators. Canadian Social Trends, (Winter), (Catalogue 11-008E), 35.

Statistics Canada. (1995b). Annual labour force estimates, 1964-1994. Canadian Social Trends, (Spring), (Catalogue 11-008E), 34. 